\section{The evidence for native coconuts growing in Australia}

\author{
André Leu \\ International Director, Regeneration \\ International, Australia
}

\begin{abstract}
The coconut (Cocos nucifera L.) is not considered to be a native species in Australia due to the belief that the early European sea captains and botanists did not find coconut trees. A search of their reports shows that they regularly found evidence of coconuts including green and fresh nuts. Mature coconut trees were found from 1848 onwards. The indigenous knowledge, linguistics and oral history about coconuts is evidence that they grew in Australia prior to European colonization in 1788. A fossil coconut and fossils of Cocos pollen are evidence that they may have been in Australia for millions of years.
\end{abstract}

\section{Introduction}

The coconut (Cocos nucifera L.) is a widespread tropical coastal Indo-Pacific species that grows in conjunction with other widespread coastal species such as Callopyllum inophyllum, Terminalia cattapa, Hibiscus tiliaceus, Scaevola taccada, Casuarina equisetifolia and Ficus microcarpa. While all of these species can be found in multiple countries, including Australia, the coconut, is not regarded as a native species there. ${ }^{1}$

The belief that coconuts are not native is based on reports that the early European mariners and botanists did not find any coconut trees. Consequently, coconuts are regarded as introduced invasive weeds to be destroyed. Indigenous Australians and other researchers believe that coconuts are native and that the unique Australian types are being lost and must be preserved. A search was done on indigenous languages, the fossil records and the accounts of the first European sea captains and botanists to find evidence in order to resolve the issue of coconuts being native to Australia.

Generally, if a plant was in Australia before European colonization in 1788 , it is considered to be native. ${ }^{2}$

The classification of coconut phenotypes is complex and still evolving as more research gets published. A simple analysis is sufficient for this article. Coconuts are divided into Indo-Pacific and Indo-Atlantic forms. The Indo-Pacific form is divided into two main phenotypes of coconuts based on clear morphological characteristics - niu kafa and niu vai. ${ }^{3}$

The wild-type, niu kafa, is well adapted for spending many months at sea crossing oceans to colonize new lands because of its thicker husk with 3-sided angular shape giving it a keel that can dig a trench into the sand so it can plant itself. It and its intermediate types colonized much of the tropical Indo-Pacific. The fossil records show that they were in PNG 4,000 years ago and in Vanuatu 5,000 years ago. 3,4

Research shows that coconuts had colonized the islands of the Pacific as far out as Tahiti thousands of years before the arrival of humans. There is evidence that coconuts were in the Cook Islands over 8000 years ago, 7,000 years before the arrival of the first humans. ${ }^{3}$ Niu kafa and intermediate varieties clearly had the ability to drift less than 100 kilometers from the Torres Straits to colonize coastal Australia.

On the other hand, niu vai is not as well suited for long distance drifting due to its thinner husk. Its spread has been done primarily by humans who introduced it to new areas for cultivation because of its superior nut qualities. ${ }^{4}$

\section{Traditional owners, indigenous languages}

The Guugu Yimithirr word for coconut, Keremande, was recorded by Parkinson in the Endeavour river in $1770 .^{5}$ The dictionaries produced by the Australian Society for Indigenous Languages have multiple words for coconuts and coconut trees. The Tiwi Islander's used the word, Arlipwa for coconut tree and Pirimajirripuwa for the coconuts. The Iwaidja people of the Cobourg Peninsular and Croker Island used the word Kaluku for the coconut tree and the nut. The Maung people of nearby Goulburn Island also used the word Kaluku for the coconut tree and the nut. The Djinang of Arnhem Land used Gurlwirri for coconut palm. ${ }^{6}$

The first published Kuku Yalanji dictionary was compiled by Henry and Ruth Hershberger and fluent Kuku Yalanji elders. They recorded the word, Jirimandi, for coconut. ${ }^{7}$ They also recorded distinct place names for groves of coconut trees. A coconut grove near the mouth of Emmagen Creek, north of Cape Tribulation was called Kulngurbu. The Kuku Yalanji clearly distinguished this grove from the beach. The name for the beach is Ngamujin and the lower end is called Kaliway because it is an important story site.
Correspondence: André Leu, PO Box 800, Mossman, Queensland, Australia.

Tel.: +61428459870

E-mail: andreleu.al@gmail.com

Key words: Cocos nucifera L., Indo-Pacific species, coconut management, niu kafa, niu vai.

Conflict of interest: The author declares no conflict of interest.

Funding: The author self-funded this research.

Received for publication: 18 November 2020 Revision received: 24 November 2020.

Accepted for publication: 27 November 2020.

This work is licensed under a Creative Commons Attribution-NonCommercial 4.0 International License (CC BY-NC 4.0).

${ }^{C}$ Copyright: the Author(s), 2021

Licensee PAGEPress srl, Italy

International Journal of Plant Biology 2021; 12:9025 doi:10.4081/pb.2021.9025

Jijamali was the name for a coconut grove on the southern bank of the Bloomfield River. Giving these groves their own unique names shows that the traditional owners placed great significance on them; significant enough to name them as distinct sites. ${ }^{7}$

In 1848, the naturalist, John MacGillivray, recorded the word Waraba for coconut in the Djagaraga (Gudang) language of the indigenous people of Cape York. $^{8}$

Tucker recorded the word Kunga for coconut in the Lockhart River language. He also recorded that the traditional owners said coconut palms were always there, they owned trees and that they also made a range articles from coconut husks and shells. $\mathrm{He}$ wrote: "...the coconut is known to them by their own dialectal name and features in certain traditional ceremonial and culinary arts." 9

Hynes and Chase recorded that the traditional owners of the Temple Bay and Lockhart River said the coconuts had always been there, families owned coconut trees and they regard them as a native species. The Temple Bay traditional owners planted nuts that were surplus to the food needs of their children, above the high tide line. ${ }^{10}$

The fact is multiple traditional owners state that coconuts have always been in Australia, owned trees, had words for them, specific names for groves, and used them for food, artifacts and ceremonies. This 
should be enough evidence to accept that they were growing on the Australian mainland prior to European colonization in 1788 and by definition are native to Australia.

\section{The fossil records}

The authoritative book, Australian Palms: Biogeography, Ecology and Systematics by John Dowe cites a fossil identified as Cocos nucifera L. that dated from the late Pliocene which means that it is over two and a half million years old. Dowe cites research on finding fossils of Cocos pollen dating from the Miocene in Australia. This indicates that coconuts may have been in Australia for more than five million years. ${ }^{11}$

\section{The early Sea Captain records}

The earliest documented, evidence of coconuts in Australia was reported by Cook, Banks and Parkinson in June-August 1770 when they recorded finding nuts in and around the Endeavour River and Lizard Island, in the present-day State of Queensland.

Banks records finding coconuts in the vicinity of the Endeavour River, on July 1 and July 5. He wrote: "Here I found innumerable fruits, many of Plants I had not seen in this countrey; among them were some Cocoa nuts that had been open'd (as Tupia told us) by a kind of Crab, calld by the Dutch Beurs Krabbe (Cancer Latro) that feeds upon them." 12

No such crab exists in Australia. More likely scenarios were being opened and eaten by the traditional owners or the giant white-tailed rat (Uromys caudimaculatus), a native species that commonly feeds on coconuts.

Cook wrote on August 14, 1770, as his boat, The Endeavour, was departing Lizard Island. "I had forgot to mention in its proper place that not only of these Islands but in severl places on the Sea beach in and about Endeavour River we found Bamboos, Cocoa-nutts, the Seeds of Plants, and Pummick Stones which were not the produce of this Country from all the discoveries we have been able to make oin it. it is reasonable to suppose that they are the produce of some Country lying to the Eastward and brought here by the Easterly Trade winds."13

Because Cook and Banks did not find coconut palms, they assumed the nuts had drifted in from Pacific islands and this started the belief that coconut palms were not growing in Australia.

Cook and Banks found bamboo washed up along beaches and because they didn't find any bamboo plants, they assumed these had drifted in from a distant country. There are two species of bamboos, Neololeba atra and Mullerochloa moreheadiana, that are native to the nearby rainforests and could easily drift to the Endeavour River and Lizard Island.

Cook and Banks also mentioned that they found seeds of plants washed up on the beaches that they did not think came from Australia. The majority of seeds that are on the beaches in Queensland come from native plants that grow along the coast, rivers and estuaries of Queensland.

On May 28, 1789, Captain Bligh landed on Restoration Island, Queensland, after a marathon journey in a small boat from near Tahiti after the mutiny of the Bounty. He wrote: "Many pieces, of cocoa-nut shells and husk were found about the shore, but we could find no cocoa-nut trees, neither did I see any on the main." 14 He could not see 20 kilometers to the beach at Lockhart River or 30 kilometers to Temple Bay where according to Hynes and Chase, and Tucker, the traditional owners stated trees were growing. ${ }^{9,10}$

A few days later on June 1 on Saunders Island, Bligh wrote: "In my walk round the island, I found several cocoa-nut shells, the remains of an old wigwam., and the backs of two turtle..."14 Pieces of coconut husks and the shells cannot float for long before becoming water logged and sinking. The husks and shells that Bligh found most likely were either the result drift nuts being consumed on the islands or from consumed nuts drifting from nearby on the mainland.

Blight never set foot on the mainland and the two times he came close to it, he felt too intimidated by the presence of the traditional owners to land on the shore. He did not want to go close to the coast as they did not have any weapons and were frightenedof being attacked with no way of defending themselves. Consequently, he missed seeing any coconut palms growing along the coast.

Mathew Flinders wrote, in A Voyage to Terra Australis Vol 2, about finding a coconut shell on Aken's Island in Shoalwater Bay. Flinders wrote on September 3, 1802: "Upon the south-east side of Aken's Island, there was thrown up a confused mass of different substances; including a quantity of pumice stone, several kinds of coral, five or six species of shells, skeletons of fish and sea snakes, the fruit of the pandanus, and a piece of cocoanut shell without bernacles or anything to indicate that it had been long in the water... $" 15$
Flinders' observation that it had not been in the water for long shows that it had not drifted far. A piece of coconut shell could not have floated more than a thousand kilometres from the Torres Straits or the nearest Pacific islands as it would have become water logged and sunk. It would have come from a nearby tree.

Flinders sailed outside the Great Barrier Reef from just north of Cape Upstart until Murray Island in the Torres Straits to avoid Cook's coral reef 'labyrinth', missing coconut palms on the coast.

Alan Cunningham, the botanist on Captain Phillip Parker King's surveys on the Mermaid wrote on April 7, 1818, that he planted a coconut he found on South Goulburn Island on North Goulburn Island off the north coast of Arnhem Land. He wrote: "A cocoa nut, found on the sands near the watering place at the other island, I planted near the beach."16

Captain King wrote, in the Narrative of a Survey Volume 1, about finding a fresh green coconut on June 16,1819 at Cape Cleveland, south of present-day Townsville, that he believed came from a nearby tree. "Near the extremity of the Cape some bamboo was picked up, and also a fresh green coconut that appeared to have been lately tapped for the milk."17 Cunningham wrote in his diary that the green coconut was found in a traditional owner's village on the shore. They did not see them however they saw their fresh footprints in the sand. ${ }^{16}$

This find is significant. Green coconuts quickly turn brown after either falling or being picked from a tree. Consequently, it could not have drifted more than a thousand kilometres from Pacific islands or the Torres Straits. It had to have come from a nearby tree.

King recorded finding several coconuts above the high tide line on a beach near the mouth of the Endeavour River on July 5, 1819. ${ }^{17}$

Cunningham, reported finding coconuts at Lizard Island during Kings' third voyage in 1820. "On the 6th of August, I landed on Cook's Lizard Island (where a whaler's ton butt and several cocoanuts-one quite sound and perfect - were found upon the beach)..."16

On July 3, 1839, Captain J. Lort Stokes of the Beagle reported finding coconuts on Lizard Island. "Two old coconuts and large quantities of pumicestone were picked up on the south-east side of the island." 18 The fact that Cook found coconuts on Lizard Island in 1770, Cunningham found them in 1820 and Stokes found them in 1839 shows that they were regularly drifting to there.

On July 11, Stokes recorded finding evidence of coconuts on Boydan Island 
(now Boydong Island). "We crossed it accordingly in every direction, and discovered the remains of native fires, near which great quantities of turtle bones, and some coconut shells were scattered about."18

Stokes stated that all the inhabited Torres Straits Islands within 30 nautical miles of Australian mainland had coconuts trees.

He missed seeing coconuts trees on the Australian coast as they were "keeping about seven miles from it". ${ }^{18}$ Seven nautical miles is almost $13 \mathrm{kms}$, a distance that make it impossible to see individual trees.

Jukes, the naturalist on the Fly, wrote on August 6, 1843, in Narrative of the Surveying Voyage of HMS Fly During the Years 1842-1846, that although they hadn't found coconut trees they had found fresh coconuts on the beaches of the eastern Queensland coast. The mention of finding fresh coconuts shows that they hadn't drifted far. ${ }^{19}$

\section{The first records of coconut trees}

John MacGillivray, the naturalist on the HMS Rattlesnake, recorded finding two small groves of coconuts on Russell Island in the Frankland group. He described the mature trees full of nuts while conducting natural history research there between June 12 and June $19,1848 .^{8}$

As coconuts live for between 70-100 years, the mature trees would have started growing in the latter part off the 1700s, long before any record of Europeans spreading coconuts along the Queensland coast. Given that there were two groves, that would have started from the germination of one or two nuts and that these groves had multiple trees that had to be the result of several generations, indicates that they could have been there for hundreds of years. The Rattlesnake undertook the first comprehensive survey of the shore, botany, geology as well as the islands and reefs of the inner passage of the Great Barrier Reef, which explains why they were the first expedition to find coconut palms.

The Russell Island groves were visited by the Dalrymple expedition on October 14,1873 and again in November and December that year to collect coconuts. Hill, the expedition's botanist stated in his report that the two groves consisted of 28 trees of various sizes and that some of the trees were over 50 feet ( 15.5 meters) high. He also reported that sailors were cutting down the trees to get the nuts and that the coconut-groves were threatened. ${ }^{20}$

These groves are clear proof that there were mature coconut palms growing along
Queensland's eastern coast prior to European colonization.

Baron Ferdinand von Mueller in Fragmenta Phytographiae Australiae 186566 , lists a mature coconut tree growing at a traditional owner's settlement at Cawarral in the Keppel Bay region. ${ }^{21}$

The collector, Anthelme Thozet, wrote in a letter to the editor published in The Sydney Morning Herald, Wednesday, 6 January 1869: "It was only six years after a large population had settled on the basin of the Fitzroy River that the first information of the existence of a cocoanut tree growing at Cawarral was given by Mr. Robert Spencer. I shortly after secured specimens of the leaves, flowers, and fruits for identification, which I forwarded in November, 1864, to our illustrious Australian botanist Dr. Ferd. von Mueller."22

He described the tree: “... its height about forty-five feet; its stunted and crooked growth near the base shows unmistakable proof of the many struggles it has sustained against hurricanes and bush fires. The nuts it bears are rather small, limited in quantity, and below the average of those borne by a vigorous plant."

"It would, however, be difficult to make any correct estimate about the age of the tree in question; but I venture to say that it is above sixty years old." 22

Bentham and Mueller writing in Flora Australiensis in 1878, used it as a type specimen for an Australian coconut, which should have been sufficient to resolve the debate over coconuts being native. They describe the nuts as small, angular and 3 sided. These are distinct niu kafa nuts, the wild type of the coconut, rather than the large round nut of the cultivated niu vai form. ${ }^{23}$

This area of Keppel Bay was still occupied by the traditional owners as they hadn't been dispossessed by Europeans until 1870, six years after Thozet sent the specimens to Mueller, clearly showing that this tree was growing long before European colonization there. Flinders report in 1802 of a coconut shell that had no signs of being in the water long at nearby Shoalwater Bay is further evidence of bearing coconut palms in the region.

The first mariners clearly missed mature trees on Russell Island and Keppel Bay as well as the trees that the traditional owners stated existed at the mouth of Emmagen Creek, Bloomfield River, Lockhart River and Temple Bay.

The Russell Island coconuts are a good example. The description by MacGillivray and a drawing of the trees by Brierly in 1848 show that large mature trees existed prior to European contact. ${ }^{1,8}$ They would have been mature groves of coconuts when Cook sailed past in the dark at 6 am on June 9, 1770 and named the Frankland Islands (Russell Island is in the Franklin group). ${ }^{13}$

Flinders missed them because he sailed well outside the outer reef. ${ }^{15}$ Captain Stokes of The Beagle sailed past them at night on June $1839 .{ }^{18}$ The most interesting example is when King visited the Frankland Islands on June 17, 1821 and went to the aid of 2 ships there, and did not report seeing coconuts palms, even though they were mature trees then. ${ }^{17}$ This clearly shows that mariners and their botanists can sail close to the trees and miss them.

\section{Conclusions}

The information that early mariners and botanists did not report finding coconut trees until 1848 cannot be used as proof they did not exist in Australia. It is only proof that they either did not see them or did not report seeing them before then. They regularly found evidence of coconuts including green and fresh nuts in the inner reef coast and islands. Some of these nuts must have come from nearby trees rather than floating in from the Torres Straits or Pacific Islands, which in many cases were over a thousand kilometres away. Two groves of mature coconut trees were found 1848. The indigenous knowledge, linguistics and oral history that coconuts have always been in Australia must be taken as evidence that they grew in Australia. Finally, a fossil coconut along with fossils of Cocos pollen is evidence they may have been in Australia for millions of years.

More than one hundred coastal IndoPacific species are found in Australia. It defies logic to suggest that all these species drifted to Australia and established themselves, however one of the best adapted species for drifting and colonizing coasts, Cocos nucifera L., did not drift 30 nautical miles (56 kilometers) from the Torres Strait Islands, as reported by Stokes in 1846, to the Australian mainland and establish plants on the coast. ${ }^{18}$

The management of coconuts in Australia should be based on the fact that they were growing on the Australian mainland before 1788 and are therefore a native species. Most importantly there needs to be a program to identify and preserve the unique Australian niu kafa and intermediate types. The historical groves on Russell Island and at the mouth of Emmagen Creek have disappeared. Only two trees exist further along Emmagen Beach and these are in danger of being lost. These trees are examples unique Australian coconut phenotypes 
and are part of the valuable, genetic biodiversity of this continent. Losing them means the extinction of unique Australian flora. Coconut management needs to change from the belief that all coconuts are introduced invasive weeds and should be destroyed to preserving the unique Australian types in situ in their preferred ecological environments.

\section{References}

1. Dowe J, Smith L. A brief history of the coconut palm in Australia. Palms 2002;46:134-8.

2. Fensham R, Laffineur B. Defining the native and naturalised flora for the Australian continent. Austral J Botany 2019;67:55-69.

3. Nayar N. The Coconut: Phylogeny, Origins, and Spread, Academic Press, 2016.

4. Buckley R, Harries H. Self-Sown WildType Coconuts from Australia. Biotropica 1984;16:148-51.

5. The Australian Society for Indigenous Languages (AuSIL), Dictionaries. Available from: http://ausil.org.au /node/3717 (Accessed Nov. 2, 2020)

6. Parkinson S. Parkinson's Journal: Daily Entries. Available from: http://southseas.nla.gov.au/journals/parkinson/194. html (Accessed Nov. 2, 2020)
7. Hershberger H, Hershberger R. Kuku Yalanji Dictionary 1982, Reprinted 1998. Available from: http://www.ausil.org.au/sites/ausil/files/ WP-B-7\%20English\%20-\%20KukuYal\%20Dict._0.pdf

8. MacGillivray J. Narrative of the Voyage of the HMS Rattlesnake. T\&W Boone, London: 1852.

9. Tucker R. Palms of Subequatorial Queensland, Palm and Cycad Societies of Australia (PACSOA). 1988. Available from: http://www.pacsoa.org. au/palms/Cocos/nucifera_oz.html

10. Hynes R, Chase D. Plants, Sites and Domiculture: Aboriginal Influence upon Plant Communities in Cape York Peninsula. Archeol Oceania 1982;17:1.

11. Dowe J. Australian Palms: Biogeography, Ecology and Systematics. CSIRO Publishing, Collingwood, Vic, Australia, 2010.

12. Banks J. Bank's Journal: Daily Entries. Available

from: http://southseas.nla.gov.au/journals/ban ks/17700705.html (Accessed Nov. 2, 2020)

13. Cook J. Cook's Journal: Daily Entries. Available from: http://southseas.nla. gov.au/journals/cook/17700814.html (Accessed Nov. 2, 2020)

14. Bligh W. A Voyage to the South Sea. George Nicol, Pall Mall, London, 1792.

15. Flinders M. A Voyage to Terra Australis. Vol 2. George Nicol, Pall Mall, London,
1814.

16. Lee I. Early Explorers in Australia. From the Log-Books and Journals, Methuen \& Co., London, 1925.

17. King P. Narrative of a survey of the intertropical and western coasts of Australia. Performed between the years 1818 and 1822; with an appendix containing various subjects relating to hydrography and natural history. Vol 1 , Murray, 1827.

18. Stokes J, Discoveries in Australia. Vol. 1 Vol. 2. T\&W Boone, London 1846.

19. Jukes J. Narrative of the Surveying Voyage of HMS Fly: During the Years 1842-1846, Volume 1,T\&W Boone, London, 1847.

20. Dalrymple G, Narrative and reports of the Queensland North East Coast Expedition 1873, Queensland Government Printer, 1874.

21. Mueller F von, Fragmenta Phytographiae Australiae. Vol. 5. Government of Victoria, Melbourne, 1865-66.

22. Thozet A. Letter to the editor published in The Sydney Morning Herald, Wed 6 January, 1869.

23. Bentham G, von Mueller F. Flora australiensis: a description of the plants of the Australian territory, L. Reeve and co., London, 1878. 